region in Siberia. The high standard and the quality of print and illustrations of these publications are in no small measure due to the editorial board presided over by Prof. E. K. Lazarenko.

Besides these publications of the Society, there is also Uchonye Zapisky (Scientific Annals) of the University of Lvov, the Geological Series of which is edited by Prof. O. S. Vyalov.

The library of the Society contains more than 10,000 volumes and is constantly growing, partly due to a large number of exchanges with other societies, both at home and abroad.

S. I. TOMKEIEFE

\section{SOCIOLOGY IN THE UNITED STATES}

$\mathrm{F}$ OLLOWING publication of its "International Register of Current Team Research in the Social Sciences", Unesco's series "Documentation in the Social Sciences" is now being extended by the addition of three reports covering recent trends in economic, political science and sociological research in the United States (Unesco : 19 Avenue Kléber, Paris, $16^{\mathrm{e}}$.). In view of the enormous amount of social science research that is being pursued there, it has been thought most appropriate to give a bird's eye view of general tendencies and preoccupations rather than seek to catalogue in detail all that is being done over a given time by every serious researcher. These reports have been commissioned from eminent specialists who are in close touch with developments and whose accounts constitute an authoritative guide to progress within these three major disciplines.

The work on sociology has been edited by Hans L. Zetterberg, of Columbia University, who traces its considerable growth in the past decade. In 1945, the American Sociological Society had 1,242 regular members; in 1954, 4,350 members-a gain of 250 per cent. Among about two thousand institutions offering instruction on a higher than secondary level, about 98 per cent have prospectuses listing courses under the heading 'sociology'. On the average, the four-year college offers about a dozen different sociology courses. It would appear that at least a third of the college population in the United States, during one time or another in their college career, follows a sociology course and that about one out of ten Americans at the age of twenty has followed at least one class in sociology. The bulk of students enrolling in sociology courses do so during their first or second year of college, that is, at an age between seventeen and nineteen. The majority of those teaching sociology to undergraduates in American colleges are indeed best compared with teachers in upper-sixth forms in grammar schools.

Slightly less than 2 per cent of college students choose sociology as their major field of concentration. Since there is no established occupation or profession of 'sociologist', these students select sociology with other vocational interests in mind.

About one-fifth select teaching and one-quarter various forms of social work, while one-tenth take up personnel work in industry. Many of the courses deal with marriage and family life, social problems and criminology. The social problems courses are not designed to help students 'solve' social problems but rather to open their eyes to their existence and to prepare them for participation in democratic discussion of these problems.
Some sixty universities offer graduate instruction in sociology and grant higher degrees. In 1953, for example, 14l Ph.D.s in sociology were awarded by these institutions.

The organization of an American graduate department in sociology shows several interesting contrasts with its European counterpart. For example, a typical European sociology department has one professor who is the administrative head and who also sets the tone for the scholarly orientation of the department. An American graduate department, on the other hand, contains several professors who do not usually represent the same school of thought; in fact, university administrators often make efforts to obtain representation from different specializations and occasionally even contradictory emphases. This gives the student a chance to learn different aspects of sociology without having to go to different universities. The graduate departments of sociology are also centres of sociological research, and most sociological projects undertaken in the United States are headed by a university professor. Most of these projects involve a staff of several people in addition to the person in charge. The excellence of American training in sociology is in no small part due to the widespread possibility for students to participate as research assistants in projects where they can learn this uncodified research tradition.

Several leading universities have found it convenient to organize separate agencies to handle larger aspects of social science research. Some of these agencies are adjuncts to the sociology departments, such as the Bureau of Applied Social Research at Columbia University and the National Opinion Research Centre at the University of Chicago; others are more independent agencies like, for example, the Research Centre for Group Dynamics at the University of Michigan. Several of these agencies are interdisciplinary in character and practice and may include psychologists, anthropologist3, political scientists and economists.

The fact that more than one person is involved in the typical sociological research project means that the long tradition of research by the lone scholar has been broken. This type of organization makes it possible to complete large-scale projects in a short time, whereas the solitary research worker might have to spend a long time completing the routine office work which constitutes 90 per cent of modern sociological research. This organized research increases the power of the worker involved; he can undertake larger projects and complete them in a shorter time. It also increases the efficiency of the research worker, since few sociologists can claim excellence in all the varied tasks that enter into a project.

On the other hand, organized research has come into conflict with the traditional procedures of awarding academic and scholarly recognition, which are still based on evaluation of contributions submitted by one scholar.

It is plain that sociological research in the United States, precisely because it is organized research, is expensive research; the average sociological project probably costs more than the average project in history, political science or economics. During the past decade the proportion of government support. has decreased somewhat, while the proportion of foundation support has increased. The most important agencies have employed prominent sociologists on their staff, and it is the practice among 
nearly all of them to consult with university socio. logists before acting on a proposal. This means that academic representatives maintain the main part of the control over available funds.

In Europe it is, on the whole, more difficult to get subsidies for research than subsidies for the publication of research. In spite of the great amount of support for research in the United States, there is both proportionately and absolutely little subsidy to publish scholarly reports. This means that the number of monographic reports published in the United States is lower than one would expect in view of the total volume of research. Elementary textbooks appear to be about the only risks that most commercial publishers are willing to take. To simplify the students' task of locating important articles, a number of so-called 'readers' have appeared during the past decade which reprint in book form a series of articles related to a given topic.

In a survey of recent research projects in American sociology, Zetterberg shows that the common charge that sociology merely elaborates the obvious is often without justification. For example, it has been generally held that insanity-rates have increased as society becomes more urbanized and industrialized. Goldhamer and Marshall have shown that over the past century in the State of Massachusetts there has been no such increase. Numerous commentators have expressed the view that the rate of social mobility has declined over the past decades in the United States. The study of intergenerational occupational mobility by Rogoff and the study of access to the business élite by Keller show no general decline, although the avenues to success might be different from in the past. It has long been an axiom that the rate of social mobility is higher in the United States than in Western Europe : examination of the available evidence by Lipset and Rogoff fails to sustain this belief. Democratic ideologists have glorified the voter who first listens to all the arguments and then makes up his independent mind to deliver his vote. The election studies by Lazarsfeld et al. and Berelson et al. show that group pressures in most cases determine the way the vote is cast and that the voter who does not make up his mind until the campaign is over is likely to be the least informed and the most confused.

The rest of the book gives detailed surveys of work which has been carried out in the past decade or so under the headings of method and theory, social institutions and groups, rural and urban sociology, sociology of social stratification, criminology, sociology of ethnic relations and the sociology of mental health.

\section{TRIGONIA: A LIVING FOSSIL}

$\mathrm{A}$

$T$ the close of the Mesozoic era the bivalve Trigonia gradually became less abundant in European seas and, to all appearances, soon became extinct. Their shells do not occur as fossils in the rocks formed during Tertiary time, and geologists were convinced that they had died out. Donald F. McMichael has described how the French naturalist, Peron, who, with his fellow collectors on the voyage of the French exploration ship Geographe, found on a beach in southern Tasmania a shell which seemed to be the same as well-known fossils. Back in France, the great zoologist, Lamarck, described the shell as the first living Trigonia, calling it T. margaritacea because of its beautiful iridescent interior (Aust. Mus. Mag., 12, No. 3; 1956).

Two other lirench naturalists, Quoy and Gaimard, who sailed with the Astrolabe, carried out searches for a living specimen. In King George's Sound and in Westernport, Victoria, occasional dead valves were found, but none alive. The first was hauled up in Bass Strait, among deep-sea animals and debris, and this was followed by other living specimens. The discovery of these living fossils must have excited as much interest at the time as did the finding of the first living coelacanth. It was as important from the scientific point of view.

The shells are placed in a separate family, the Trigoniidae, which includes a number of different genera, and many distinct species. Of these, only six are living to-day, and all are found along the Australian coast. Later research has revealed that the shells do occur as fossils in the Tertiary rocks of Australia, where alone they have persisted since Mesozoic time.

The present-day species are placed in the genus Neotrigonia. Because of their delightful lustre, the common name for them is brooch shells, and they are used for shell jewellery. The exterior of the shell is marked with a series of radiating ridges and nodules, and the hinge 'teeth' are large and strongly serrated; these features are characteristic of the group.

All the living species of Neotrigonia occur in fairly deep water, between 10 and 100 fathoms, and only dead shells are seen on the beaches after storms.

\section{PHOSPHATE FERTILIZERS}

TN a recent publication* by the Organization for 1 European Economic Co-operation, results of all suitable experiments in Western Europe that compare phosphate fertilizers made by processes which economize in sulphuric acid with other well-known phosphates have been collected and correlated by G. W. Cooke. The report is based on summaries of work carried out in their countries by rapporteurs from the Low Countries, Scandinavia, Austria, France, Germany, Italy, Portugal, Switzerland, Ireland and the United Kingdom. Occasional reference is made to comparable experiments in the United States.

The report emphasizes that the values of alternative phosphate fertilizers depend on the crops for which they are applied; unprocessed rock phosphates are satisfactory, for example, for swedes on acid soils, but potatoes make little use of this fertilizer and require water-soluble phosphates. The evaluation of fertilizers in both pot and field experiments is de. scribed, but most of the conclusions are based on extensive series of field experiments; results from 379 experiments with dicalcium phosphate and 537 experiments with phosphates produced by thermal processes are summarized in the report.

The main classes of phosphate fertilizers discussed are dicalcium phosphate, nitrophosphates, phosphates produced by high-temperature processes and compound fertilizers containing ammonium phosphates. Powdered dicalcium phosphate dihydrate is equivalent to superphosphate. Nitrophosphates that con-

* "The Agricultural Value of Phosphate Fertilizers which economize in the Use of Sulphuric Acid". By Dr. George W. Cooke, Rothamsted Experimental Station, Project No. 162. (Organization for Furopean Pconomic Co-operation, Paris, 1950.) 